\title{
Knowledge Level of Agricultural Extension Agent and Farmers' to Response the Climate Change in Pringsewu Distric, Lampung Province, Indonesia
}

\author{
Irwan Effendi; Abdul Mutolib; Indah Listiana; Helvi Yanfika; Kordiyana K Rangga ${ }^{1}$; Ali Rahmat ${ }^{2}$ \\ ${ }^{1}$ Department of Agricultural Extension, Faculty of Agriculture, University of Lampung , Indonesia \\ ${ }^{2}$ The United Graduate School of Agricultural, Gifu University, Japan
}

http://dx.doi.org/10.18415/ijmmu.v6i1.993

\begin{abstract}
The objective of this research is to analyze the knowledge level of agricultural extension agency and farmers about climate change and its effects on their perception and response in Pringsewu Regency, Lampung Province, Indonesia. The research was conducted in Enggalrejo Villages from April to May 2018. The research location was chosen purposively since both villages are agricultural centers of the regency. The method used a qualitative research approach. The data was collected through in-depth interviews from 3 key informants consisting of agricultural extension staff and 30 farmers. Key informants were identified using snowball sampling. This research applied KAP (Knowledge, Attitude, Practice) approach with three classifications namely low, medium, and high. The results showed that the staff knowledge, attitude, and practice of agricultural extension related to climate change and its relation to agriculture was low. It was also found that farmers have been aware of climate change due to rainfall uncertainty and adjusted it through changing/shifting the cropping period. Farmers agree that climate change affects agriculture. The response of farmers to climate change: shortage varieties, farming without tillage, early harvesting period, use of herbicides to accelerate weeding, and diversification of agricultural commodities as the adaptation strategy.
\end{abstract}

Keywords: Climate Change; Agricultural Extension Staff; KAP Approach; Farmers

\section{Introduction}

The whole world has recognized that global warming has affected almost all aspects of life. According to Crosson (1997), the increase in global temperatures due to doubling of CO2 gas concentrations has led to a global temperature increase between $1.0-3.5^{\circ} \mathrm{C}$. The increase in temperature was followed by an increase in the average of $10-15 \%$ precipitation due to a more atmospheric warmly binds more moisture.

Climate change is something that is difficult to avoid and has an impact on various aspects of life. Agriculture is known to be the sector most vulnerable to the impacts of climate change. In Indonesia, the impact of climate change has significant implications, especially for national food security. Overall, the 
extreme climate has caused a decline in production from the previous level of only $2.4 \%-5.0 \%$ to more than 10\% (Hasanah, Lesmana, and Imang, 2017). Although according to many results, the research states that the agricultural sector contributes to greenhouse gases production; the agricultural sector remains a source of food for the whole world. Surmaini et al. (2011) and IPCC (2014) state that agricultural activities contribute emissions $14 \%$ of total emissions in 2000 and the most abundant source (97\%) was derived from rice production and biomass burning. In the future, food crop production will face pressure from water availability, rainfall, and attacks by plant disturbing organisms. For the tropics, the decline in production is estimated to reach $10-20 \%$ in line with the increase in the local temperature of $1-5^{\circ} \mathrm{C}$.

Based on these facts, it will be a big problem in dry climates where the availability of water and rainfall is the primary key to the sustainability of food crop farming. Also, farmers and assisting officers are not ready to anticipate these changes and mitigation technology (Gintings et al., 2003). Potential losses that will be faced by farmers can be reduced by applying location-specific adaptation and mitigation technologies based on land conditions. The application of planting calendar technology (Runtunuwu et.al, 2013) regulating irrigation water rotation (Estiningtyas et al, 2012), the use of adaptive varieties, reorientation of new agricultural areas, optimization of abandoned land, development of climate insurance (Research and Development Agency, 2011) are some research results as efforts to answer the challenges of climate change on agriculture. However, not all farmers consciously carry out adaptation actions that have a mitigative impact or prevent climate change. The climate is a determining factor in establishing cropping patterns and planting sequences in one year (Sukartaatmadja, 2000; Mutolib et al, 2016; Hamid, 2018). Adaptation is one of the policy choices to reduce the negative impacts of climate change (Adger et al., 2003; Arbuckle, Morton, and Hobbs, 2015). Adaptation to climate change refers to adjustments in natural or human systems in response to actual or estimated climate stimuli from the effects of climate change that are significantly detrimental or potentially profitable (IPPC, 2001; Trait and Hanna, 2015). The adaptation action taken is not free from the knowledge possessed by the farmer himself. Besides farmers, agricultural extension staffs are actors whose roles are vital in agricultural development and interact directly with farmers. Therefore, it is imperative to know how the level of knowledge of agricultural extension staffs on climate change.

This study aims to determine the level of knowledge of agricultural extension agency/staff on climate change and the response of farmers to climate change in Enggalrejo Village, Adiluwih District, Pringsewu Regency Lampung. This study does not limit farmers to fixed commodities but involves all farmers with various commodities in Enggalrejo Village.

\section{Materials and Methods}

\section{Time and Place of Research}

This research was carried out for two months starting from July to August 2018. The research location was in Enggalrejo Village, Adiluwih District, Pringsewu Regency Lampung. The location of the research was the center of corn production in the Adiluwih Subdistrict, so the research respondents were almost all corn farmers.

\section{Sampling Method}

Enggalrejo Village, Adiluwih District, Pringsewu Regency Lampung was chosen as the location for conducting the research purposively (deliberately) because it is one of the corn centers in Pingsewu 
Regency. The sampling method in this study was conducted by purposive sampling (judgmental). Purposive sampling is a sampling technique not based on random or strata but based on the existence of considerations that focus on specific goals (Arikunto, 2006). The research sample consisted of two respondents consisting of Agricultural Extension and Adiluwih District BP4K (agricultural agency) officers. While the sample of farmers was 30 respondents (Arikunto, 2006).

\section{Data Analysis Techniques}

The research method used in this study is a qualitative approach, where the research conducted is descriptive. Descriptive research is research conducted to find out or describe the reality of events under study. In addition, descriptive research is also limited to efforts to express problems, circumstances or events as they are so that they are merely used to reveal facts and provide an objective picture (Nawawi, 2007).

The level of knowledge of agricultural extension staff and farmers' responses to climate change analysis with approaches Knowledge, Attitudes, and Practices (KAP). A "KAP" survey is a representative study of a specific population that aims to collect data on what is known, believed and done in relation to a particular topic (Zahedi, et al. 2014).

Data analysis techniques used in this research to find out the knowledge and adaptation of farmers are by using qualitative data methods, which use data quality of research objects that is the size of data in the form of non-numbers but is a quality (eg good, bad, high, low). According to Miles and Huberman (1994), qualitative data analysis includes data collection stage, data reduction stage or data simplification, data presentation stage, and discussion phase/conclusion drawing all research results.

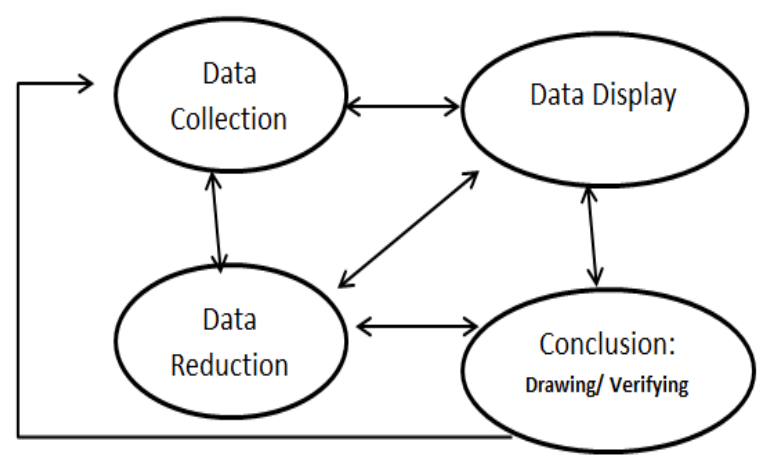

Figure 1. Interactive Model of Analysis (Miles and Huberman, 1994).

\section{Results and Discussion}

\section{Profile of Research Area}

Enggalrejo Village is one of the thirteen villages in Adiluwih District, Pringsewu Regency. It has an area of $9.48 \mathrm{~km} 2$ or 948 ha and consists of four hamlets. The number of families is as many as 385 families and a population of 1,273 people. The density of the population of Enggalrejo Village is 368 people / km2 The population of Enggalrejo Village is predominantly Muslim, and some are Christians, Catholics and Hindus. 
Adiluwih District is a center of agricultural production in Pringsewu Regency. It has an area of 498 ha of agricultural land with details of 6 ha of rice fields and 492 fields of rice fields (rainfed land). The main commodities in Enggalrejo Village are corn and vegetables. Corn commodities are planted twice a year, while vegetables were grown throughout the year. When in the dry season, farmers use watering from boreholes or water sources made independently by farmers. More than $95 \%$ of Enggalrejo Village residents work in the agricultural sector (Central Bureau of Statistics of Pringsewu, 2017).

\section{General Description of Research Respondents}

The interviewee's respondents are 33 farmers and 3 agricultural extension staffs and BP4K (agricultural agency) of Adiluwih. The general description of the research was shown in Table 1.

Table 1. Profile of research respondents

\begin{tabular}{|l|l|l|}
\hline No & Identity & Description \\
\hline 1 & Number of Respondents & 3 agricultural extension / BP4K officers 30 farmers \\
\hline 2 & Gender & 23 male and 7 female \\
\hline 3 & Average age & 36.70 years \\
\hline 4 & Education & 6 Not graduating from elementary school \\
& & 15 respondents elementary school \\
& & 5 graduated from junior high school \\
& & 4 graduated from high school \\
\hline 5 & Average length of stay & 29.32 years \\
\hline 6 & Farming & 21 corn farmers \\
& & 9 corn and vegetable farmers \\
\hline
\end{tabular}

\section{Level of Knowledge of Agricultural Extension Agency on Climate Change}

The results of the interviews with agricultural extension staffs from Enggalrejo village and BP4K from the sub-district of Adiluwih gave an overview in general, the level of knowledge of agricultural extension staff in Enggalrejo Village regarding climate change is low. Agricultural extension staff do not understand what is meant by climate change properly. Also, the agricultural extension staff is hesitant about the relationship between climate change and the decline in agricultural productivity. The lack of knowledge of agricultural extension staffs on climate change issues was caused by the absence of counselling and socialization from related parties. The low of intensity of counseling and extension give the impact on the level of knowledge and capacity of agricultural extension agent on the latest issues in agriculture (Yanfika, Listiana, Mutolib, Rahmat, 2019. Due to lack of knowledge about climate change, there has been no effort or mitigation, which is carried out by agricultural extension staffs in addressing the current climate change. Overview knowledge of agricultural extension in the village Enggalrejo was shown in the following Table 2.

Table 2. Knowledge of agricultural extension staff on climate change

\begin{tabular}{|l|l|l|l|}
\hline Question & Yes & Doubt & No \\
\hline Have you heard about the term climate change? & $\mathrm{X}$ & & \\
\hline Do you understand the significance of climate change? & & $\mathrm{X}$ & \\
\hline Has there been any counselling and socialization about climate change? & & & $\mathrm{X}$ \\
\hline Is there a link between climate change and agriculture? & & $\mathrm{X}$ & \\
\hline Climate change can reduce agricultural production & & $\mathrm{X}$ & \\
\hline $\begin{array}{l}\text { Changes in cropping seasons, drought and unstable rainfall intensity are symptoms } \\
\text { of climate change. }\end{array}$ & & $\mathrm{X}$ & \\
\hline Have you ever conducted counseling on farmers related to climate change? & & & $\mathrm{X}$ \\
\hline Are there any efforts being made to prevent climate change? & & & $\mathrm{X}$ \\
\hline
\end{tabular}




\section{Farmers' Knowledge about/on Climate Change}

Climate change has caused many losses in agricultural sectors. One of the parties directly affected by the phenomenon of climate change is farmers. Farmers are very vulnerable to the impacts of climate change because each activity is very dependent on rain and erratic changes in the rainy season that directly affect farming.

Changes in the growing season and high rainfall has led to a decrease in corn production which became the primary commodity in Enggalrejo Village. The high intensity of rain during the growing season will cause the corn crop to collapse, and water to be flooded. That will interfere with corn growth and reduce productivity.

Based on the results of the interviews with farmers, it was perceived that most of the farmers have heard about the term climate change. However, the majority of them do not know appropriately about climate change. Nonetheless, $100 \%$ of the research respondents understand uncertainty occurred and a shift in the planting season believing that this is related to climate change. There have been changes in the growing season and uncertainty felt by farmers in the last 15 years. Some things that have changed include: A shifting and uncertain planting season. All farmers planted at the beginning of September and ended in March, but at this time it was not known exactly when to plant. Currently, farmers start planting in November and December. That indicates that there has been a shift in the planting season.

- Crop failure. In the past 10 years, at least twice the farmers have experienced crop failure. It is because dry season comes faster, while the rainy season is shorter than usual. As a result, many corn crops fail to harvested due to lack of water.

- Extreme rainfall causes the fall of corn. Then, high winds (pickaxe) often appears to sweep corn plants and cause collapse and crop failures.

\section{Farmers' Response/Adaptation To Climate Change}

Although they do not understand climate change well, farmers in Enggalrejo Village understand that there is a lot of uncertainty in today farming. Therefore, farmers have anticipated several steps. Farmers' adaptation to changes and uncertainties of climate by using of early maturing (faster harvesting), farming without tillage, harvest acceleration, the use of herbicides to accelerate weeding, and diversification of agricultural commodities.

Use of the short ages varieties. Uncertainty and the short planting season (rainy period) cause farmers to choose corn varieties that are faster to harvest. Usually, farmers will harvest 100-day corn crops for planting. Now, use of early harvesting varieties to anticipate the short rainy season to avoid crop failure due to lack of water.

Farming without tillage. One of the adaptations made by corn farmers in Enggalrejo Village to overcome the uncertainty of the planting season and the short of the rainy season is by avoiding tillage. The land is only ploughed during the first planting season, and in the second planting season, the farmers do not plough the land. After harvesting and clearing land from corn stalks, farmers will immediately replant the corn without processing the land. Soil processing is considered to be able to prolong the growing season. At least one hectare of tillage takes about a week when using human labor, and two to three days when using a plough/tractor. 
Accelerating the harvesting season. The adaptation strategy used by farmers to deal with the uncertainty of the season is to accelerate the harvest. In the past, farmers harvested corn when it was completely dry. However, now farmers prefer to sell corn in half-wet conditions. Economically speaking, it will reduce the price of corn, but farmers can accelerate the second planting season to one to three weeks. Some farmers even sell young corn to feed animals. Selling young corn that is used for animal food can accelerate the next planting season to one month.

Use of herbicides to reduce weeding time. Usually, farmers in Enggalrejo village will clear corn fields after the first planting season. However, the short rainy season causes farmers to replant corn quickly. After the corn has been harvested, the corn plant will be immediately cleared and replanted without cleaning the grass such in first planting season. Land clearing will prolong the planting time because it takes about one week to clear the land.

Diversification of agricultural commodities. Uncertainty in trying to cause farmers to innovate by planting commodities other than corn that is faster to harvest. The number of commodities planted will provide benefits when the main crop fails. Some farmers share their land with two commodities such as corn and vegetables/nuts. Some farmers apply inter-cropping system on one land, for example planting cassava between corn crops. This can anticipate if there is a crop failure in the main commodity.

\section{Conclusion}

The level of knowledge of agricultural extension and local officials of BP4K in Adiluwih Sub District about climate change is low. Agricultural extension workers do not understand the meaning of climate change and its relation to agricultural productivity. The lack of knowledge of agricultural extension workers is caused by the absence of training or socialization related to climate change. Agricultural extension workers do not come from farmers and as a result they do not deeply understand the relationship between climate change and agriculture. This is different from the knowledge of corn farmers in Enggalrejo Village who, although they do not know the exact meaning of climate change, they are deeply aware of climate change. Climate change, according to farmers, is marked by a shift in the growing season, uncertainty of the planting season, and the shortness of the rainy season. The response or adaptation of farmers in Enggalrejo village to scientific changes (this is related to the uncertainty of the season, etc. includes: shortage varieties, farming without tillage, early harvesting periods, use of herbicides to accelerate weeding, and diversification of agricultural commodities.

\section{references}

Adger, W.N., Huq, S.K.,Brown, D., Conway, Hulme, M. (2003). Adaptation to Climate Change in The Developing World. Progess in Devalopment Studies. Asian Development bank Institure. Japan.

Arbuckle, J. G, Morton, L.W. and Hobbs, J. 2015. Understanding Farmer Perspectives on Climate Change Adaptation and Mitigation: The Roles of Trust in Sources of Climate Information, Climate Change Beliefs, and Perceived Risk. Environment and Behavior, 47(2): 205-234.

Arikunto, S. (2006). Prosedur Penelitian: Suatu pendekatan Praktik (Jakarta: Rineka Cipta). 
Badan Penelitian dan Pengembangan Teknologi Pertanian. (2011). Pedoman Umum Adaptasi Perubahan Iklim Sektor Pertanian (Jakarta: Badan Litbang Pertanian).

BPS Kabupaten Pringsewu. (2017). Kecamatan Adiluwih dalam angka 2017. (Pringsewu: Badan Pusat Statistik Kabupaten Pringsewu).

Crosson, P. (1997). Impacts of Climate Change on Agriculture Climate Issues Brief No. 4. (Washington, DC: Resources for The Future). 1616 P Street NW. Washington, DC 20036.

Estiningtyas, W, R. Boer, I. Las, A. Buono. (2012). Identifikasi dan Delineasi Wilayah Endemik Kekeringan Untuk Pengelolaan Resiko Iklim di Kabupaten Indramayu. Jurnal Meteorologi dan Geofisika. Vol 13 (1). Hal: 9-20.

Gintings et.al. (2003). Anomali dan perubahan iklim sebagai peluang untuk meningkatkan hasil perikanan dan ketahanan pangan. Perhimpunan meteorologi pertanian indonesia (PERHIMPI). Bogor.

Hamid, MA., Nurtanto, M., Rahmat, A., Mutolib, A., Nurhaji, S., Fawaid, M., Rizal, SU. 2018. The Analysis of Learning Implementation Plan (LIP) in Vocational Subjects Based on 2013 Curriculum. Advances in Social Science, Education and Humanities Research (ASSEHR), 161: 27-32.

Hasanah, U., Lesmana, D., and Imang, N. (2017). Pengetahuan dan Adaptasi Petani Padi Sawah Terhadap Perubahan Iklim Di Girirejo Kelurahan Lempake Kecamatan Samarinda Utara. Jurnal Ekonomi Pertanian dan Pembangunan, 14(2): 64-77.

IPCC. (2014). Food Security and Food Production System Impact in Adaptation and Vulnerability. Working Paper Group II Contibution to AR5. [diakses tanggal 10 Agustus 2018]. Tersedia dari http://www.ipcc.ch/report/ar5/wg2/.

Miles, M. B.,\& Huberman, A. M. (1994). Qualitative Data Analysis An Expanded Sourcebook. Thousand Oaks, CA Sage Publications.

Mutolib, A., Yonariza, Y., Mahdi, M., Ismono, H. 2016. Gender Inequality and the Oppression of Women within Minangkabau Matrilineal Society: A Case Study of the Management of Ulayat Forest Land in Nagari Bonjol, Dharmasraya District, West Sumatra Provinece, Indonesia. Asian Women, 32(3): 23-49.

Nawawi, H. (2007). Metode Penelitian Bidang Sosial. Yogyakarta: Gdjah Mada University Press.

Runtunuwu, E, H. Syahbudin, F. Ramadhani. (2013). Kalender Tanam Sebagai Instrumen Adaptasi Perubahan Iklim. Dalam: Soeparno H, Pasandaran E, Syarwani M, Dariah A, Pasaribu SM, Saad NS, editors. Politik pembangunan pertanian menghadapi perubahan iklim. Jakarta (ID): IAARD Press. Hal. 271-297.

Sukartaatmadja, S. (2000). Pedoman penentuan suatu pola tanam. Laboratorium Teknik Tanah dan Air. Jurusan Teknik Pertanian. Fakultas Teknologi Pertanian. IPB. Bogor.

Surmaini, E., E. Runtunuwu dan I.Las. (2011). Upaya Sektor Pertanian Dalam Menghadapi Perubahan Iklim. Jurnal Litbang Pertanian No 30 (1). Hal: 1-7. 
Tait, P.W and Hanna, E. G. 2015. A Conceptual Framework for Planning Systemic Human Adaptation to Global Warming. International Journal of Environmental Research and Public Health, 12(9): 10700-10722.

Yanfika,Y. Listiana, I., Mutolib, A. and Rahmat, A. 2019. Linkages between Extension Institutions and Stakeholders in the Development of Sustainable Fisheries in Lampung Province. Journal of Physics: Conference Series, 1155 (01201), 1-9.

Zahedi, L.; Sizemore, E.; Malcolm, S.; Grossniklaus, E.; Nwosu, O. (2014). Knowledge, attitudes and practices regarding cervical cancer and screening among Haitian health care workers. Int. J. Environ. Res. Publ. Heal. 11, 11541-11552.

\section{Copyrights}

Copyright for this article is retained by the author(s), with first publication rights granted to the journal.

This is an open-access article distributed under the terms and conditions of the Creative Commons Attribution license (http://creativecommons.org/licenses/by/4.0/). 